\title{
Do Cultural Values Affect the Implementation of Smart Living Policy in Yogyakarta City?
}

\author{
Suranto $^{1, *}$ Dewi Sekar Kencono ${ }^{2}$ Muhammad Iqbal $^{3}$ \\ ${ }^{1}$ Department of Government Studies, Universitas Muhammadiyah Yogyakarta, Indonesia \\ ${ }^{2}$ Department of Government Studies, Universitas Muhammadiyah Yogyakarta, Indonesia \\ Doctoral of Public Administration, Departement of Public Policy and Management, Universitas Gadjah Mada, \\ Indonesia \\ ${ }^{3}$ Department of Political Science, National Cheng Kung University of Taiwan \\ *Email: suranto@umy.ac.id
}

\begin{abstract}
This paper aims to explore the extent of cultural values that affect the implementation of smart living policy in Yogyakarta, which is indicated by aspects of safety, health and culturally vibrant and happiness. Yogyakarta is wellknown as a comfortable city to live in as well as high life expectancy, has now been facing a global phenomenon, such as the decrease in the quality of public services, reduced availability of residential area, traffic congestion, limited parking spaces, swelling levels of energy consumption, accumulation of garbage, increasing crime rates. Therefore, Yogyakarta City implements policy of smart living to the criteria and concepts of how to manage a quality of life. This study used both primary and secondary data collection methods from government officers, representatives of society, and Jogja Smart Service Applications and other supporting documents. The data collection techniques are interview, observation and documentation. The results showed that the application of smart living in Yogyakarta City much considered to the local wisdom and cultural values adopted by the community, for the aspect of the role of the Palace (Kraton) is still significant make the community more obey regular rules. Besides, in the aspect of health, the city government has implemented technology in its service process, which is applied to the Community Health Center. Finally, in the aspect of safety, public transport governance focused on the accessibility and inclusiveness to support community mobility.
\end{abstract}

Keywords: Smart Living, Culture Values, Quality of Life, Yogyakarta City

\section{BACKGROUND}

The nomination of Yogyakarta City as the Ten Best Tourism Destinations in Indonesia by Traveler's the Choice Award 2017 ignites the City to continue improvement in managing and developing tourism sector [1]. Based on the great potentials in various sectors such as education, tourism, technology and the active participation of the society, the Yogyakarta City Government in collaborated with the Central Government eager to develop Yogyakarta as a Smart City [2], [3].

Smart living is a part of the six areas of the smart city concept that discusses the criteria and concepts of how to manage a better quality of life and habits (culture) in a region [4]. Usually, a certain city has its own standards for quality of life due to the culture values or customs. The World Health Organization Quality of Life Group stated that the quality of life is an individual's perception of their position in life in the context of the cultural and value systems in which they live and concerning their goals, hopes, values and concerns combining physical health, psychological states, the level of independence, social relationships, personal beliefs and their relationship with salient features of environmental quality refers to subjective evaluations embedded in cultural, social and environmental contexts [5].

The current Yogyakarta City development planning focuses on environmental and sustainability aspects, directly related to urban issues [6], [7]. However, the Yogyakarta's sustainable development is now facing global problems, such as a decline in the quality of public services, reduced availability of residential area, 
Traffic congestion, limited parking spaces, swelling levels of energy consumption, waste issues, increasing crime issues, and other social problems [8], [9]. Obviously, the City has limited capacity to overcome the problems quickly if still using conventional patterns [10]. So, there should be a smart efforts and solutions to solve the problem by implementing and collaborating with urban ecosystems which is part of the Smart City concept. This concept is considered as a solution to overcoming various problems.

\section{LITERATURE REVIEW}

Based on Carragliu et al. stated that cities will be smart if there are investments in human resources, social capital and traditional and modern communication system infrastructure [11]. These factors can increase both sustainable economic growth and quality life with resource management through participatory governance. Besides, [12] [13] [14] [15] divides the smart city concept into six dimensions, which are (Figure 1).
a. Smart economy;
b. Smart mobility;
c. Smart environment;
d. Smart people;
e. Smart living; and
f. Smart governance

Meanwhile [16] [17] argues that one more dimension related to smart cities, namely smart disaster management which close related to the issues of Indonesian geographic condition that lies in the ring of fire.

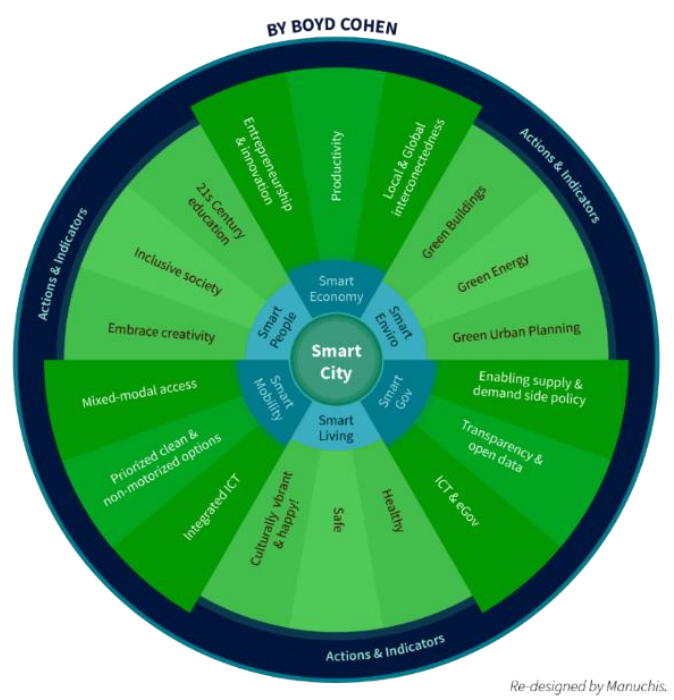

Figure 1. Dimensions of Smart City

Sources: [12]
This research will focus on implementation of Smart Living in Yogyakarta City. Smart living is an environment that can provide comfort, the sustainability of resources, physical and non-physical beauty, visual or not, for the community and the public based on the values of local customs and culture $[4 ; 18]$. Smart living also covers a friendly environment, mainly by providing complete access to public services, technical and social infrastructure, a high level of security, a broad culture and a friendly environment for its residents [13]. This smart city has become successful in several developing countries, apart from the initiatives that have made this smart city successful, other factors are [12] [14] [19]

Table 1. Indicators and Are Working Smart Living

\begin{tabular}{|c|c|c|}
\hline Dimensions & Work Area & Indicators \\
\hline \multirow{8}{*}{ Smart Living } & \multirow{4}{*}{$\begin{array}{l}\text { Culture and } \\
\text { Well-being }\end{array}$} & Living conditions \\
\hline & & Gini Index \\
\hline & & Ranked quality of life \\
\hline & & Investment in Culture \\
\hline & \multirow{2}{*}{ Security } & Crime \\
\hline & & Smart Crime Prevention \\
\hline & \multirow{2}{*}{ Health } & Single medical history \\
\hline & & Life expectancy \\
\hline
\end{tabular}

Sources: Cohen, 2012; Kassim et, al. 2019

Smart living encourages the creation of a livable city that ensures the quality of life society in the city. The viability of life can be measured by three elements, which are [20] [21] [22]
a. The feasibility of a healthy environmental quality
b. Eligibility of health quality
c. Feasibility of transportation modes to support the mobility of people

Livable City is a city where people can live comfortably and quietly in a city. A livable city is a city that can accommodate all urban community activities and is safe for all people [23] [24]. As a tangible form to realize the idea of development as an improvement in the quality of life, it requires physical and social habitats. Sustainable development will have an impact on a place that is safe, comfortable, environmentally friendly as a place for people to live independently and have a high life expectancy [5].

Table 2. Strategies for Realizing Smart Living

\begin{tabular}{|l|l|}
\hline $\begin{array}{l}\text { Sub Pilar } \\
\text { Dimention }\end{array}$ & \multicolumn{2}{|c|}{ Strategies } \\
\hline Culture & $\begin{array}{l}\text { Harmonization of regional spatial } \\
\text { planning and local community trust }\end{array}$ \\
\hline Health & a. Increasing accessibility and \\
\hline
\end{tabular}




\begin{tabular}{|c|c|}
\hline & quality of public health with ease \\
\hline & $\begin{array}{l}\text { b. Increasing access to health } \\
\text { services through an integrated } \\
\text { information system }\end{array}$ \\
\hline \multirow{4}{*}{ Mobility } & $\begin{array}{l}\text { 1. Create an integrated } \\
\text { transportation system with traffic } \\
\text { engineering management and } \\
\text { compliance transportation service } \\
\text { infrastructure facilities }\end{array}$ \\
\hline & $\begin{array}{l}\text { 2. More optimal management of } \\
\text { public street lighting (smart street } \\
\text { lighting) }\end{array}$ \\
\hline & $\begin{array}{l}\text { 3. Protecting the environment from } \\
\text { vehicle pollution by } \\
\text { implementing an online } \\
\text { motorized vehicle testing system }\end{array}$ \\
\hline & $\begin{array}{l}\text { 4. Providing public transportation } \\
\text { that provides connectivity } \\
\text { between regions }\end{array}$ \\
\hline
\end{tabular}

Sources: [25]; [26]; [27]

Based on the explanation above, the hypothesis in this study are (figure 2)

H-1: Culture has a significant effect on smart living implementation

H-2: Health has a significant effect on smart living implementation

H-3: Mobility has a significant effect on smart living implementation

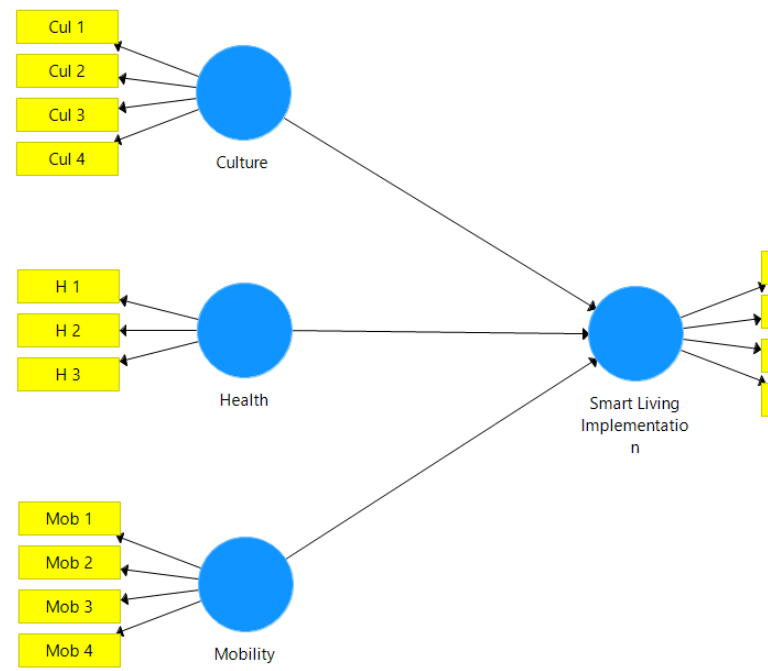

Figure 2 Theoritical Framework

\section{RESEARCH METHOD}

The study applies survey research method using quantitative research method to answer the research questions. Both questionaires and literature study are the main instrument of data collection which covered data of culture, health, mobility and implementation of smart living. The population consist of 388.627 people of Yogyakarta city inhabitants, who 100 persons are the sample which was determined by Slovin's formula.
Then, SmartPLS 3.0 software is applied to analyze data, using outer model analysis and inner model analysis.

\section{RESULT AND DISCUSSION}

\subsection{Demographic Profile of Respondents}

The table 3 shows that the number of respondents based on gender consists of $71 \%$ male respondents and $29 \%$ female respondents. Meanwhile, based on age, the respondents are predominantly by age of 21-20 years by $40 \%$. There were $32 \%$ of respondents who aged $31-40$ years old and $28 \%$ of respondents were more than 40 years old. In addition, most respondents are Bachelor degree as many as $49 \%$ respondents. Furthermore, $37 \%$ respondents are high school.

Table 3 Respondents' Demographic Profile

\begin{tabular}{|c|c|c|}
\hline Variables & Number & Percentage $(\%)$ \\
\hline \multicolumn{3}{|l|}{ Gender } \\
\hline Male & 71 & 71 \\
\hline Female & 29 & 29 \\
\hline \multicolumn{3}{|l|}{ Age } \\
\hline 21-30 years & 40 & 40 \\
\hline $31-40$ years & 32 & 32 \\
\hline$>40$ years & 28 & 28 \\
\hline \multicolumn{3}{|l|}{$\begin{array}{l}\text { Education } \\
\text { Level }\end{array}$} \\
\hline $\begin{array}{l}\text { Junior } \text { High } \\
\text { School }\end{array}$ & 4 & 4 \\
\hline $\begin{array}{ll}\text { Senior } & \text { High } \\
\text { School } & \end{array}$ & 37 & 37 \\
\hline Bachelor & 49 & 49 \\
\hline Graduate & 10 & 10 \\
\hline
\end{tabular}

\subsection{Validity and Reliability Analysis}

The validity test result (table 4) shows that all variables which are culture, health, mobility and smart living implementation in Yogyakarta City have an Average Variance Extracted (AVE) value greater than 0.500 . The AVE value is valid if the AVE score is more than 0.50 [28]. Based on the criteria, all variables are declared valid.

Meanwhile, the reliability test using Composite reliability and Cronbach's Alpha shows that the construct is reliable if the values are above 0.70 [28]. The validity test result (Table 4) shows that both composite output reliability and Cronbach alpha were above 0.70 . So each construct in the estimated model has good reliability.

Table 4 Validity and Reliability Test

\begin{tabular}{|l|l|l|l|}
\hline Variables & $\begin{array}{l}\text { Cron } \\
\text { bach } \\
\text { Alph } \\
\text { a }\end{array}$ & $\begin{array}{l}\text { Composite } \\
\text { Reliability }\end{array}$ & AVE \\
\hline Culture & 0.904 & 0.933 & 0.776 \\
\hline Health & 0.837 & 0.902 & 0.753 \\
\hline
\end{tabular}




\begin{tabular}{|l|l|l|l|}
\hline Mobility & 0.897 & 0.928 & 0.764 \\
\hline $\begin{array}{l}\text { Smart Living } \\
\text { Implementation }\end{array}$ & 0.865 & 0.908 & 0.712 \\
\hline
\end{tabular}

\subsection{Path coefficients and hypothesis testing}

The results of the study in Figure 3 show that smart living implementation in Yogyakarta City is influenced by culture, health and mobility by $\mathrm{R}^{\wedge} 2$ $=0.671$ or $67.1 \%$. If associated with the Rule of Thumb for testing R Square according to [28] the structural model which has an R-square $(\mathrm{R} \wedge 2)$ result of 0.67 indicates that the model is "good", $\mathrm{R}$ square $\left(\mathrm{R}^{\wedge} 2\right)$ is 0.33 indicates that the model is "moderate", and the R-square $(\mathrm{R} \wedge 2)$ is 0.19 indicating that the model is "weak". So it can be concluded that the variables that affect the smart living implementation variable have an excellent level of influence.

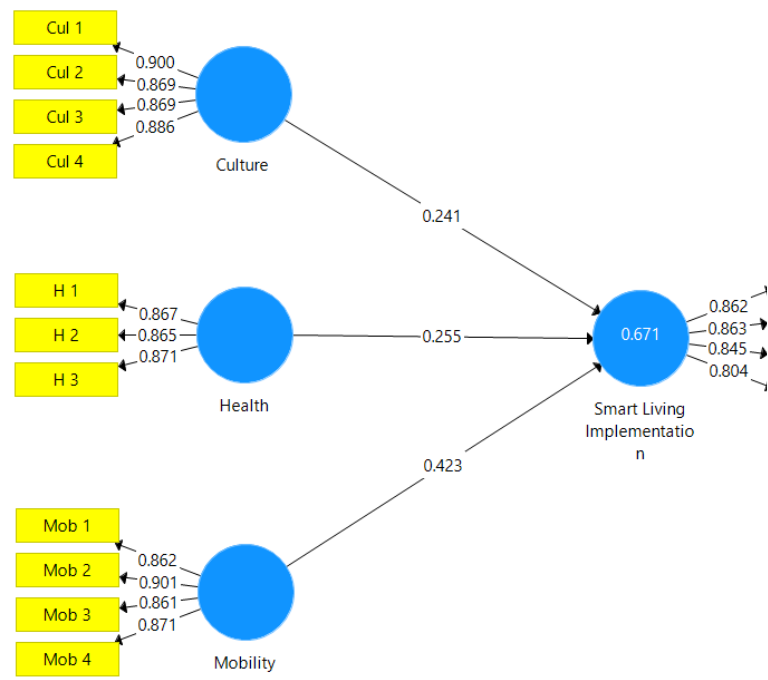

Figure 3 Outer Model in Smart Living Implementation

Hypothesis testing between variables, namely exogenous variables against endogenous variables $(\gamma)$ and endogenous variables against exogenous variables $(\beta)$, was carried out using the bootstrap resampling method after seeing the validity and reliability of the data. The test statistic used is the $t$ statistic or t-test. The comparative $t$ value in this research is obtained from the $t$ table. The test is declared significant if the statistical value $\mathrm{T}>1.96$ and the value of the $\mathrm{P}$-value $<0.05$ [29]. Hypothesis testing is done by looking at the output path coefficient of bootstrap resampling. The results can be seen from Table 5.

Table 5 Hypothesis Testing

\begin{tabular}{|l|l|l|l|c|}
\hline \multicolumn{1}{|c|}{ Variables } & $\begin{array}{c}\text { Original } \\
\text { Sample }\end{array}$ & $\begin{array}{c}\text { T - } \\
\text { Statistic }\end{array}$ & $\begin{array}{c}\text { P- } \\
\text { Value }\end{array}$ & State \\
\hline $\begin{array}{l}\text { Culture -> } \\
\text { Smart Living } \\
\text { Implementation }\end{array}$ & 0.241 & 2.181 & 0.030 & Accepted \\
\hline $\begin{array}{l}\text { Health -> } \\
\text { Smart Living } \\
\text { Implementation }\end{array}$ & 0.255 & 2.078 & 0.038 & Accepted \\
\hline $\begin{array}{l}\text { Mobility -> } \\
\text { Smart Living } \\
\text { Implementation }\end{array}$ & 0.423 & 3.520 & 0.000 & Accepted \\
\hline
\end{tabular}

The results show that cultural values have a significant effect on the implementation of smart living in the city of Yogyakarta. These findings indicate that culture has an essential role in implementing smart living in the city of Yogyakarta. This is similar to the branding of Yogyakarta City as a cultural city in Indonesia. In line with the vision of the Yogyakarta City, it is "a City of Education-Quality, Character and Inclusion, Culture-Based Tourism, and Service Center with Environmental and Social Economic Insights". This vision has 4 (four) keywords, namely tourism, education, culture and service center. These four keywords will be developed as a goal of developing a smart city in the Yogyakarta city, with the central being smart culture.

The concept of the smart culture built by the Yogyakarta city government is also supported by smart living that prioritizes cultural values in city governance. The cultural concept is Memayu Hayuning Bawono, Catur Sagotra, Sangkan paraning dumadi and Golong Gilig, Sawiji - greget - sengguh ora mingkuh. The components of the city space, which are a manifestation of this cultural concept are the Tugu axis - Kraton Panggung Krapyak, Malioboro area, Njeron Beteng area. The concept of culture that manifests in the urban space includes the concept of Метауи Hayuning Bawono, Manunggaling Kawulo Gusti, Sangkan Paraning Dumadi and Pathok Negoro. Then an attitude to life that is rooted and reflected in the concept of sawiji-gregetsengguh-oramingkuh. The embodiment of these concepts in urban spatial planning can be seen in the following table 6 :

Table 6 Concepts in Urban Spatial Planning in Yogyakarta City

\begin{tabular}{|c|l|l|}
\hline Cultural concept & The form in the city space & \multicolumn{1}{|c|}{ Evaluation } \\
\hline Memayu Hayuning Bawono & Catur Gotro Tunggal or & Catur Gotro Tunggal is a Javanese cosmological \\
& Catursagotro, Jalinan 4 & concept, namely the harmony of the micro and macro \\
& Yogyakarta city icons: & cosmos. The Kraton (palace) as the leader, the \\
& Kraton - Masjid Gede - & mosque as a religion, the market as an economic \\
& Pasar Gede - Alun-Alun. & activity and the square as a reflection of culture. The \\
\hline
\end{tabular}




\begin{tabular}{|c|c|c|}
\hline & & $\begin{array}{l}\text { leadership pattern that refers to religion, economy } \\
\text { and culture is a reflection of the concept of memayu } \\
\text { hayuning bawono, which is currently known as the } \\
\text { concept of sustainable development (HB X, 2012) }\end{array}$ \\
\hline Manunggaling Kawulo Gusti & $\begin{array}{l}\begin{array}{l}\text { Monumen Tugu }- \text { Kraton } \\
\text { (Palace)- } \\
\text { Krapyak and the fastening }\end{array} \\
\text { axis. Tugu Golong - Gilig }\end{array}$ & $\begin{array}{l}\text { Tugu Golong-gilig, Palace (Kraton) and The } \\
\text { Panggung Krapyak, which is united by a north-south } \\
\text { axis, represents the union of leaders and people. In } \\
\text { everyday life this concept manifests itself in the } \\
\text { pattern of mutual cooperation }\end{array}$ \\
\hline Sangkan Paraning Dumadi & $\begin{array}{lcc}\text { Axis of } & \text { Tugu } & - \text { Kraton } \\
\text { (Palace) } & - & \text { Panggung } \\
\text { Krapyak. } & & \end{array}$ & $\begin{array}{l}\text { This concept is one of the ordinary patrons in } \\
\text { Javanese culture, a symbiosis of Hindu-Buddhist and } \\
\text { Islamic teachings. What is special and second to none } \\
\text { is the effort to make intangible concepts into tangible } \\
\text { ones. These efforts include giving street names, } \\
\text { planting certain types of plants and carrying out } \\
\text { certain ceremonies. }\end{array}$ \\
\hline $\begin{array}{l}\text { Sawiji - greget - sengguh ora } \\
\text { mingkuh }\end{array}$ & $\begin{array}{l}\text { Space configuration: the } \\
\text { palace-fortress and the } \\
\text { warrior villages behind it, } \\
\text { forming a specific traditional } \\
\text { war title pattern. }\end{array}$ & $\begin{array}{l}\text { Sawiji, greget, sengguh ora mingkuh are the } \\
\text { characteristics of Mataram knights. The spatial } \\
\text { configuration of the Jeron Beteng area and the } \\
\text { soldier's village illustrates this principle. In Kraton } \\
\text { (palace) position, which represents the Sultan as } \\
\text { Senopati Ing Ngalogo (at the end of the title, not } \\
\text { inside). The Sultan as commander must be at the } \\
\text { front, lead and set an example, such as the nature of } \\
\text { P. Mangkubumi }\end{array}$ \\
\hline
\end{tabular}

Sources: [9]

Apart from cultural values, the health variable also has a significant effect on smart living implementation in Yogyakarta City. This shows that aspects of health services to the community have an essential role in implementing smart living in the city of Yogyakarta. In the health aspect, the Yogyakarta City Government has implemented technology in its management. A total of 5 health centers in Yogyakarta City serve patient queue registration online. Registration for the community Health centers queue is done through the Jogja Smart Service (JSS) application belonging to the Yogyakarta city government. The online service is to make it easier for residents, so they don't have to come to the community Health centers first to pick up a queue number.

Besides that, the mobility aspect also has a significant influence on the implementation of smart living in Yogyakarta City. To support community mobilization, the Yogyakarta City Government provides various modes of transportation. As the principle of smart living, which requires providing public transportation that provides connectivity between regions. Interestingly, the city of Yogyakarta also maintains traditional transportation modes such as Delman and Becak, whose existence is protected by regional regulations. In addition to supporting community mobility, this mode of transportation is also a special attraction for tourists. Along with the development of the times, the Yogyakarta City government continues to maintain cultural values in the mode of transportation to support one of the indicators of smart living in the city of Yogyakarta, which is citizen mobility.

\section{CONCLUSION}

The application of a smart city is proper with various supporting aspects that need attention. In particular, the application of smart living in the Yogyakarta City, which is a city of culture, must be recognized as influencing its applications culture is inherent in the influence of the palace so that the daily lives of the residents were assimilated a long time ago. The use of culture in smart living is reflected in the arrangement of spaces and areas in the city of Yogyakarta, where the Kraton is located. So that it is considered and prioritized in maintaining the aesthetics of spatial and regional layout in the city of Yogyakarta. In addition, in terms of health services and mobility in the city of Yogyakarta, it is still preserving local cultural wisdom. One example of health services is by activating the role of the elderly to reattach cultural treasures to the next generation through retelling stories and Kaweruh Bahasa Jawa (Javanese language). For mobility also to be developed to existing historic buildings in the management of roads and pedestrians. Traditional transport, such as Pedi Cap and Wagon, continues to be used as transport icons and environmentally friendly vehicles used by the City of Yogyakarta to support the implementation of smart living. Efforts to include cultural values in the application of smart living show that culture plays a role 
in its implementation. Because culture is inherent in the city of Yogyakarta and influences all aspects of life through adaptation and advancement of culture and civilization.

\section{AUTHORS' CONTRIBUTIONS}

Suranto: Conducting research with the literature review stage, collecting data and analyzing the data that has been collected. The author also plays an active role in making journal article manuscripts starting from the background, literature review to narrating data.

Dewi Sekar Kencono and Muhammad Iqbal: the author analyzes the data and elaborates the relevant theoretical literature. The author is also actively involved in the formulation of research problems and adds a variety of relevant literature to strengthen the analysis and findings in the article.

\section{ACKNOWLEDGMENTS}

Thank you to Universitas Muhammadiyah Yogyakarta

\section{REFERENCES}

[1] Faidat, N., \& Khozin, M. (2018). Analisa Strategi Pengembangan Kota Pintar (Smart City): Studi Kasus Kota Yogyakarta. JIP (Jurnal Ilmu Pemerintahan): Kajian Ilmu Pemerintahan dan Politik Daerah, 3(2), 171-180.

[2] Iqbal, M., Pribadi, U., \& Elianda, Y. (2020). Factors affecting the citizen to use e-report application in Gunungkidul Regency. Smart Cities and Regional Development (SCRD) Journal, 4(2), 27-39

[3] Anggraini, A. T., \& Iqbal, M. (2020). The Uttilization of Jogja Smart Service Application: an E-Readiness Approach. Journal of Governance and Public Policy, 7(2), 150-159

[4] Velasco, A. A., McGrory, J., \& Berry, D. (2018, July). Patterns within patterns within the smart living experience. In Proceedings of the 32nd International BCS Human Computer Interaction Conference (p. 70). BCS Learning \& Development Ltd.

[5] Bier, N., Paquette, G., \& Macoir, J. (2018). Smartphone for smart living: Using new technologies to cope with everyday limitations in semantic dementia. Neuropsychological rehabilitation, 28(5), 734-754

[6] Jayanti, A. V., Purnomo, E. P., \& Nurkasiwi, A. (2020). Vertical Garden: Penghijauan Untuk Mendukung Smart Living Di Kota Yogyakarta. Al Imarah: Jurnal Pemerintahan Dan Politik Islam, 5(1), 41-54

[7] Amijaya, S. Y. (2020). Evaluasi Prinsip Smart Mobility Dan Smart Living Pada Kampung Jetisharjo Yogyakarta. SPACE, 7(1)

[8] Iqbal, M., Elianda, Y., Akbar, A., \&
Nurhadiyanti, N. (2020). Keistimewaan Penataan Ruang Menurut Peraturan Daerah Istimewa Provinsi Daerah Istimewa Yogyakarta. Jurnal Caraka Prabu, 4(1), 99-120

[9] Djunaedi, A. (2015). Aspek Budaya Dalam Keistimewaan Tata Ruang Kota Yogyakarta (Cultural Aspect in the Speciality of Yogyakarta Urban Spatial Planning). Journal of Regional and City Planning, 26(3), 230-252.

[10] Rachmawati, R. (2019). Utilization \& Quality of Information System for Administration Services Based on ICT In Patehan, Kraton, Yogyakarta. Indonesian Journal of Science and Technology, 4(1), 55-63

[11] A. Cocchia, (2014) "Smart and digital city: A systemic literature review", in Smart City, Progress in IS, R.P. Dameri and C. RosenthalSabroux, Eds. Switzerland: Springer International Publishing, pp. 13-43

[12] Cohen, B. (2013). Smart city wheel. Retrieved from SMART \& SAFE CITY: http://www. smartcircle. org/smartcity/blog/boyd-cohen-thesmart-city-wheel

[13] Sikora-Fernandez, D., \& Stawasz, D. (2016). The concept of smart city in the theory and practice of urban development management. Romanian Journal of Regional Science, 10(1), 81-99

[14] Kassim, N. M., Yeap, J. A. L., Nathan, S., Hashim, N. H., \& Ramayah, T. (2019). A Conceptual Paper of the Smart City and Smart Community. In Eurasian Economic Perspectives (pp. 39- 47). Springer, Cham

[15] Gunawan, H. (2018, October). Identifying factors affecting smart city adoption using the unified theory of acceptance and use of technology (UTAUT) method. In 2018 International Conference on Orange Technologies (ICOT) (pp. 1-4). IEEE

[16] Djunaedi, A. (2014). Smart City : Solusi Permasalahan Masa Depan Perkotaan di Indonesia (Sebuah Agenda Penelitian). In Seminar Nasional Smart City: Solusi untuk Permasalahan Perkotaan di Indonesia? (pp. 15). Yogyakarta, Indonesia: PSPPR UGM.

[17] Budy, P. A. (2018). Smart city narrative in Indonesia: Comparing policy documents in four cities. Вопросы государственного и муниципального управления, (6).

[18] Lai, P. C. (2015). Smart Living For Smart Cities@ the palm of your hand. Australia: Research Asia

[19] Achmad, K. A., Nugroho, L. E., \& Djunaedi, A. (2018). Smart City Readiness based on Smart City Council's Readiness Framework. International Journal of Electrical \& Computer Engineering (2088-8708), 8(1).

[20] Li, J., Jin, J., Yuan, D., Palaniswami, M., \& Moessner, K. (2015, November). EHOPES: Datacentered Fog platform for smart living. In 
2015 International Telecommunication Networks and Applications Conference (ITNAC) (pp. 308-313). IEEE

[21] Li, J., Jin, J., Yuan, D., Palaniswami, M., \& Moessner, K. (2017). A Data-centered Fog PIatform for Smart Living. In From Internet of Things to Smart Cities (pp. 357-377). Chapman and Hall/CRC

[22] Xu, H., \& Geng, X. (2019). People-centric service intelligence for smart cities. Smart Cities, 2(2), 135-152

[23] Matos, A., Pinto, B., Barros, F., Martins, S., Martins, J., \& Au-Yong-Oliveira, M. (2019, April). Smart Cities and Smart Tourism: What Future Do They Bring?. In World Conference on Information Systems and Technologies (pp. 358-370). Springer, Cham.

[24] Allam, Z., \& Newman, P. (2018). Redefining the smart city: Culture, metabolism and governance. Smart Cities, 1(1), 4-25

[25] Neve, M. (2018). Would Urban Cultural Heritage Be Smart? Culture As A Land Factor And Italian Cities'smartness. Journal of Communication and Languages, (48).

[26] Iannone, R., Gurashi, R., Iannuzzi, I., de Ghantuz Cubbe, G., \& Sessa, M. (2019). Smart Society: A Sociological Perspective on Smart Living.

[27] Fanea-Ivanovici, M., \& Pană, M. C. (2020). From Culture to Smart Culture. How digital transformations enhance citizens' well-being through better cultural accessibility and inclusion. IEEE Access, 8, 37988-38000.

[28] Ghozali, Imam. 2006. Aplikasi Analisis Multivariate dengan Program SPSS (Edisi Ke 4). Semarang:Badan Penerbit Universitas Diponegoro.

[29] Haryono, Siswoyo. 2017. Metode SEM Untuk Penelitian Manajemen Dengan AMOS LISREL PLS. Luxima Metro Media 